\title{
Degradation of herbicide S-metolachlor by electrochemical AOPs using a boron-doped diamond anode
}

\author{
Diego Roberto Vieira Guelfiª, , Fábio Gozzi ${ }^{\mathrm{a}}$, Amílcar Machulek Jr. ${ }^{\mathrm{a}}$, Ignasi Sirés ${ }^{\mathrm{b}, *}$, Enric Brillas ${ }^{\mathrm{b}}$, \\ Silvio C. de Oliveira, ${ }^{\mathrm{a}, *}$ \\ ${ }^{a}$ Instituto de Química (INQUI), Universidade Federal de Mato Grosso do Sul, Av. Senador Filinto Muller, 1555, CP 549, MS 79074-460 Campo Grande, Brazil \\ b Laboratori d'Electroquímica dels Materials i del Medi Ambient, Departament de Química Física, Facultat de Química, Universitat de Barcelona, c/Martí i Franquès 1-11, \\ 08028 Barcelona, Spain
}

\section{A R T I C L E I N F O}

\section{Keywords:}

Boron-doped diamond anode

Electro-Fenton

Electro-oxidation

Photoelectro-Fenton

S-metolachlor

Water treatment

\begin{abstract}
A B S T R A C T
The degradation and mineralization ability of electrochemical processes like electro-oxidation with electrogenerated $\mathrm{H}_{2} \mathrm{O}_{2}\left(\mathrm{EO}-\mathrm{H}_{2} \mathrm{O}_{2}\right)$, electro-Fenton (EF) and UVA-assisted photoelectro-Fenton (PEF) has been comparatively studied for solutions of the herbicide S-metolachlor. Solutions of $100 \mathrm{~mL}$ have been treated using an undivided cell equipped with an air-diffusion cathode and a boron-doped diamond (BDD) anode. The effect of $\mathrm{pH}$, current density, and $\mathrm{Fe}^{2+}$ and S-metolachlor concentrations has been thoroughly studied. The total organic carbon removal profiles have demonstrated the feasibility of almost overall mineralization by EF and PEF after $9 \mathrm{~h}$ at $300 \mathrm{~mA}$. The herbicide decays in both treatments informed about the complexation of Fe(III) ions formed from Fenton's reaction, which decelerated S-metolachlor removal. However, the high oxidation power of BDD anode allowed the gradual mineralization of such complexes. The identification of chlorinated and nonchlorinated degradation byproducts by GC-MS has allowed the proposal of main degradation routes.
\end{abstract}

\section{Introduction}

The large consumption of herbicides worldwide contributes in a very significant manner to environment contamination and, as a result, public health is currently at stake [1]. The herbicide S-metolachlor (ST, $\mathrm{C}_{15} \mathrm{H}_{22} \mathrm{ClNO}_{2}$, 2-chloro- $N$-(2-ethyl-6-methylphenyl)- $N$-[(1S)-2-methoxy -1-methylethyl]acetamide) is a selective chloroacetanilide herbicide that has been applied since the 1970s to more than 70 different crops to control small leaf weeds in the pre and post-emergence period [2]. Its high water solubility $\left(480 \mathrm{mg} \mathrm{L}^{-1}\right.$ at $\left.20^{\circ} \mathrm{C}\right)$, low vapor pressure $\left(1.73 \times 10^{-3} \mathrm{~Pa}\right.$ at $\left.20^{\circ} \mathrm{C}\right)$ and large half-life owing to its slow degradation by photolysis (70 days exposure to sunlight) or hydrolysis (30 days at pH 5-9) led to classify S-metolachlor residues as persistent $[3,4]$. Its large usage and relatively low adsorption in soil cause a considerable discharge into groundwater, thus compromising water quality [5]. Although ST is classified as moderately toxic (Class III) $[4,6]$, its negative impact on aquatic microorganisms like phytoplankton [7], fish [8] and crustaceans [9], as well as on certain types of human cells [10] has been reported. Several authors have investigated the performance of various methods to treat water containing this and other herbicides. $\mathrm{TiO}_{2}$ photocatalysis [11], photo-Fenton with artificial and natural light [12,13], electro-Fenton (EF) [14-20], and UVA- or solar-assisted photoelectro-Fenton (PEF) with in situ $\mathrm{H}_{2} \mathrm{O}_{2}$ electrogeneration $[16,20-22]$ have yielded very positive results.

The electrochemical advanced oxidation processes (EAOPs) like electro-oxidation with electrogenerated $\mathrm{H}_{2} \mathrm{O}_{2}\left(\mathrm{EO}-\mathrm{H}_{2} \mathrm{O}_{2}\right)$, EF and PEF have been progressively receiving increasing interest for the removal of toxic organic contaminants from water due to their great performance, in combination with simple setups, safe procedures and affordable costs [23-28]. They promote the oxidation of organic compounds upon in situ generation of hydroxyl radical $(\cdot \mathrm{OH})$, which exhibits a high redox potential $\left(E^{\circ}=2.8 \mathrm{~V} / \mathrm{SHE}\right)$, yielding a high degree of mineralization [29-32].

In EO, which is the most widely employed EAOP, the formation of physisorbed $\cdot \mathrm{OH}(\mathrm{M}(\cdot \mathrm{OH}))$ occurs at the surface $(\mathrm{M})$ of a non-active anode such as boron-doped diamond (BDD) from water oxidation at high applied current or potential, as shown in reaction (1) [30]. BDD is the most effective anode among those tested so far, having demonstrated its effectiveness also for the total degradation of herbicide residues $[18,30]$. Apart from its large overpotential for $\mathrm{O}_{2}$ evolution and low adsorption of any species including $\cdot \mathrm{OH}$, BDD presents very appealing technological properties such as a high mechanical, thermal and chemical resistance [32].

\footnotetext{
* Corresponding authors.

E-mail addresses: i.sires@ub.edu (I. Sirés), scolive@gmail.com (S.C. de Oliveira).
} 
$\mathrm{M}+\mathrm{H}_{2} \mathrm{O} \rightarrow \mathrm{M}\left({ }^{\circ} \mathrm{OH}\right)+\mathrm{H}^{+}+\mathrm{e}^{-}$

The EO process can be combined with the cathodic electrogeneration of $\mathrm{H}_{2} \mathrm{O}_{2}$, yielding the so-called EO- $\mathrm{H}_{2} \mathrm{O}_{2}$. Several kinds of carbonaceous materials have been used for this purpose, being carbon-PTFEbased air-diffusion cathodes especially useful because of their large ability to favor the two-electron reduction of gaseous $\mathrm{O}_{2}$ from reaction (2):

$\mathrm{O}_{2(\mathrm{~g})}+2 \mathrm{H}^{+}+2 \mathrm{e}^{-} \rightarrow \mathrm{H}_{2} \mathrm{O}_{2}$

Additional amounts of $\cdot \mathrm{OH}$ in bulk solution can be generated in $\mathrm{EF}$ from the catalytic decomposition of $\mathrm{H}_{2} \mathrm{O}_{2}$ by $\mathrm{Fe}^{2+}$ at $\mathrm{pH}$ 3.0, following Fenton's reaction (3). The catalytic cycle can be maintained since $\mathrm{Fe}^{3+}$ can be reduced at the cathode to regenerate $\mathrm{Fe}^{2+}$ via reaction (4) [29]. The oxidation ability of EF process can be enhanced upon irradiation with UVA light $\left(\lambda_{\max }=360 \mathrm{~nm}\right)$, yielding the so-called PEF process, which promotes the photoreduction of Fe(III) species from reaction (5), giving rise to additional amounts of $\cdot \mathrm{OH}$, and the photodecomposition of Fe(III)-carboxylate complexes from reaction (6) [29-32]. Note that $\mathrm{H}_{2} \mathrm{O}_{2}$ is not photolyzed to $\cdot \mathrm{OH}$ radical because this would require higher energy such as that provided by UVC light $\left(\lambda_{\max }=254 \mathrm{~nm}\right)$ [29].

$\mathrm{H}_{2} \mathrm{O}_{2}+\mathrm{Fe}^{2+} \rightarrow \mathrm{Fe}^{3+}+{ }^{\circ} \mathrm{OH}+\mathrm{OH}^{-}$

$\mathrm{Fe}^{3+}+\mathrm{e}^{-} \rightarrow \mathrm{Fe}^{2+}$

$\mathrm{Fe}(\mathrm{OH})^{2+}+h \nu \rightarrow \mathrm{Fe}^{2+}+{ }^{\cdot} \mathrm{OH}$

$\mathrm{Fe}(\mathrm{OOCR})^{2+}+h \nu \rightarrow \mathrm{Fe}^{2+}+\mathrm{CO}_{2}+\mathrm{R}^{\cdot}$

Aiming to evaluate the comparative performance of $\mathrm{EO}-\mathrm{H}_{2} \mathrm{O}_{2}, \mathrm{EF}$ and PEF to degrade the herbicide S-metolachlor, this paper presents a thorough investigation on the behavior of ST solutions treated in an undivided BDD/air-diffusion cell. The effect of $\mathrm{pH}$ on the oxidation ability of EO- $\mathrm{H}_{2} \mathrm{O}_{2}$ was studied. The influence of the applied current, and the $\mathrm{Fe}^{2+}$ and ST concentrations in EF was assessed from total organic carbon (TOC) and high-performance liquid chromatography (HPLC) measurements. The main reaction byproducts were identified by gas chromatography-mass spectrometry (GC-MS).

\section{Material and methods}

\subsection{Chemicals}

S-metolachlor (Pestanal $^{1}$ ) with purity $>98 \%$ was obtained from Sigma-Aldrich. Vetec Quimica Fina supplied the $\mathrm{Fe}_{2} \mathrm{SO}_{4} \cdot 7 \mathrm{H}_{2} \mathrm{O}, \mathrm{Na}_{2} \mathrm{SO}_{4}$ and concentrated $\mathrm{H}_{2} \mathrm{SO}_{4}$. A Gehaka DG500 UF system was employed to produce pure water (resistivity $>18 \mathrm{M} \Omega \mathrm{cm}$ ) needed to prepare all solutions to be degraded. Other chemicals used in various analytical techniques were obtained from J.T. Baker and Vetec Quimica Fina.

\subsection{Electrolytic system}

Comparative treatments of $100 \mathrm{~mL}$ of ST solutions with $0.050 \mathrm{M}$ $\mathrm{Na}_{2} \mathrm{SO}_{4}$ were carried out by EO- $\mathrm{H}_{2} \mathrm{O}_{2}, \mathrm{EF}$ and PEF using an open, undivided glass cell (capacity of $150 \mathrm{~mL}$ ) with a jacket for recirculation of water at $25^{\circ} \mathrm{C}$. During the trials, solutions were stirred using a magnetic follower. All details on the power source employed to operate galvanostatically and the UVA lamp to irradiate the solutions in PEF can be found elsewhere [20,33]. The BDD anode and carbon-PTFE air-diffusion cathode $\left(3 \mathrm{~cm}^{2}\right.$ each) used in all the experiments, conveniently cleaned and activate prior to first use [20], were purchased from NeoCoat and E-TEK, respectively. In order to ensure the $\mathrm{H}_{2} \mathrm{O}_{2}$ production along the electrolyses, the cathode was connected to an air pump (flow rate of $1 \mathrm{~L} \mathrm{~min}^{-1}$ ). It must be noted that the use of such a small electrolytic system limits the current efficiency of electrode reactions, particularly the ST removal with $\operatorname{BDD}(\mathrm{OH})$ that is controlled by the mass transport of organic pollutants.

\subsection{Instruments and analytical procedures}

The degradation of ST was monitored by HPLC using a Thermo Scientific Finnigan chromatograph equipped with: (i) an autosampler, (ii) a photodiode array detector (set a constant wavelength of $215 \mathrm{~nm}$ ), and (iii) a $5 \mu \mathrm{m}$ Agilent Technologies Zorbax Eclipse XDB-C-18 column $(250 \mathrm{~mm} \times 4.6 \mathrm{~mm})$. The mobile phase consisted in a 40:60 $(\mathrm{v} / \mathrm{v})$ $\mathrm{H}_{2} \mathrm{O} / \mathrm{CH}_{3} \mathrm{CN}$ mixture eluted at a flow rate of $0.6 \mathrm{~mL} \mathrm{~min}^{-1}$. At selected treatment times, samples were collected, immediately diluted with $\mathrm{CH}_{3} \mathrm{CN}$ and then filtered $(0.45 \mu \mathrm{m}$ PTFE filters). Chloride, chlorate, ammonium and nitrate ions were quantified following standard procedures $[34,35]$. The $\mathrm{pH}$ monitoring, TOC analysis and calculation of mineralization current efficiency (MCE) for each assay were performed as described in previous studies $[20,36]$. The number of electrons $n$ involved in the theoretical global mineralization process of ST was 74 according to reaction (7), which considers the quantitative formation of ammonium (95\% of initial $\mathrm{N}$ was accumulated as $\mathrm{NH}_{4}{ }^{+}$and $5 \%$ as $\mathrm{NO}_{3}{ }^{-}$) and chloride ions (subsequently transformed into chlorate ions).

$\mathrm{C}_{15} \mathrm{H}_{22} \mathrm{ClNO}_{2}+28 \mathrm{H}_{2} \mathrm{O} \rightarrow 15 \mathrm{CO}_{2}+\mathrm{NH}_{4}^{+}+\mathrm{Cl}^{-}+74 \mathrm{H}^{+}+74 e^{-}$

Worth mentioning, the MCE is an average value that considers globally the organic matter to be mineralized, thus ignoring the particular role of reaction intermediates which have variable oxidation state of carbon.

The main byproducts formed upon treatment of $100 \mathrm{~mL}$ of ST solutions by EAOPs were identified by GC-MS using a NIST05-MS library. For this, the samples were treated by liquid-liquid extraction method using $\mathrm{C}_{2} \mathrm{H}_{2} \mathrm{Cl}_{2}$ [20]. GC-MS analysis was made with an Agilent Technologies system composed of a $6890 \mathrm{~N}$ GC, fitted with a nonpolar Teknokroma Sapiens-X5MS or polar Agilent 19091N-133 HP Innowax column, and a 5975C MS operating in electron impact mode at $70 \mathrm{eV}$. The temperature ramp was: $36^{\circ} \mathrm{C}$ for $1 \mathrm{~min}, 5{ }^{\circ} \mathrm{C} \mathrm{min}^{-1}$ up to $250{ }^{\circ} \mathrm{C}$ (polar) or $320^{\circ} \mathrm{C}$ (non-polar) and hold time $10 \mathrm{~min}$. The temperature of the inlet, source and transfer line was 250,230 and $250-300{ }^{\circ} \mathrm{C}$, respectively.

\section{Results and discussion}

\subsection{Effect of initial $\mathrm{pH}$ on the $\mathrm{EO}-\mathrm{H}_{2} \mathrm{O}_{2}$ treatment}

For some pollutants, the initial $\mathrm{pH}$ is an important parameter in the EO- $\mathrm{H}_{2} \mathrm{O}_{2}$ treatment because it may affect the protonation/deprotonation equilibria and various reactions where protons have a role, including for example the adsorption of the molecule on the electrodes. Solutions with $0.28 \mathrm{mM} \mathrm{ST}$ and $0.050 \mathrm{M} \mathrm{Na}_{2} \mathrm{SO}_{4}$ were treated at initial $\mathrm{pH}$ of $3.0,5.0$ or 9.0 at $300 \mathrm{~mA}$ for $540 \mathrm{~min}$. The ST concentration decay shown in Fig. 1a highlights its total disappearance thanks to the oxidation by $\mathrm{BDD}(\cdot \mathrm{OH})$, requiring $240 \mathrm{~min}$ at $\mathrm{pH} 3.0$ and 5.0 and $360 \mathrm{~min}$ at $\mathrm{pH}$ 9.0. Nevertheless, the degradation was slighly faster at $\mathrm{pH}$ 3.0, which can be explained, at least in part, by the higher concentration of protons that favored the cathodic formation of $\mathrm{H}_{2} \mathrm{O}_{2}$ from reaction (2) [37]. This suggests a certain contribution of $\mathrm{H}_{2} \mathrm{O}_{2}$ to the oxidative degradation of ST. The slighly slower ST decay at pH 9.0 could also be related to the competitive oxidation of $\mathrm{OH}^{-}$to $\mathrm{O}_{2}$ at BDD without production of hydroxyl radicals [38], which causes a lower generation of $\operatorname{BDD}\left({ }^{\circ} \mathrm{OH}\right)$ from reaction (1). The inset panel of Fig. 1a presents the good fitting obtained from a pseudo-first-order kinetic analysis of the previous decays for the first $30 \mathrm{~min}$, yielding apparent rate constant $\left(k_{\mathrm{app}}\right)$ values of $0.014,0.010$ and $0.011 \mathrm{~min}^{-1}$ at $\mathrm{pH} 3.0$, 5.0 and 9.0, respectively (see Table 1 ).

Fig. 1b shows no substantial difference between the TOC removals achieved in $\mathrm{EO}-\mathrm{H}_{2} \mathrm{O}_{2}$ at those three $\mathrm{pH}$ values until $6 \mathrm{~h}$ of electrolysis, which agrees with the behavior of another herbicide like mecoprop [21]. At $9 \mathrm{~h}$, however, the mineralization attained was $96 \%$ at $\mathrm{pH} 3.0$, 

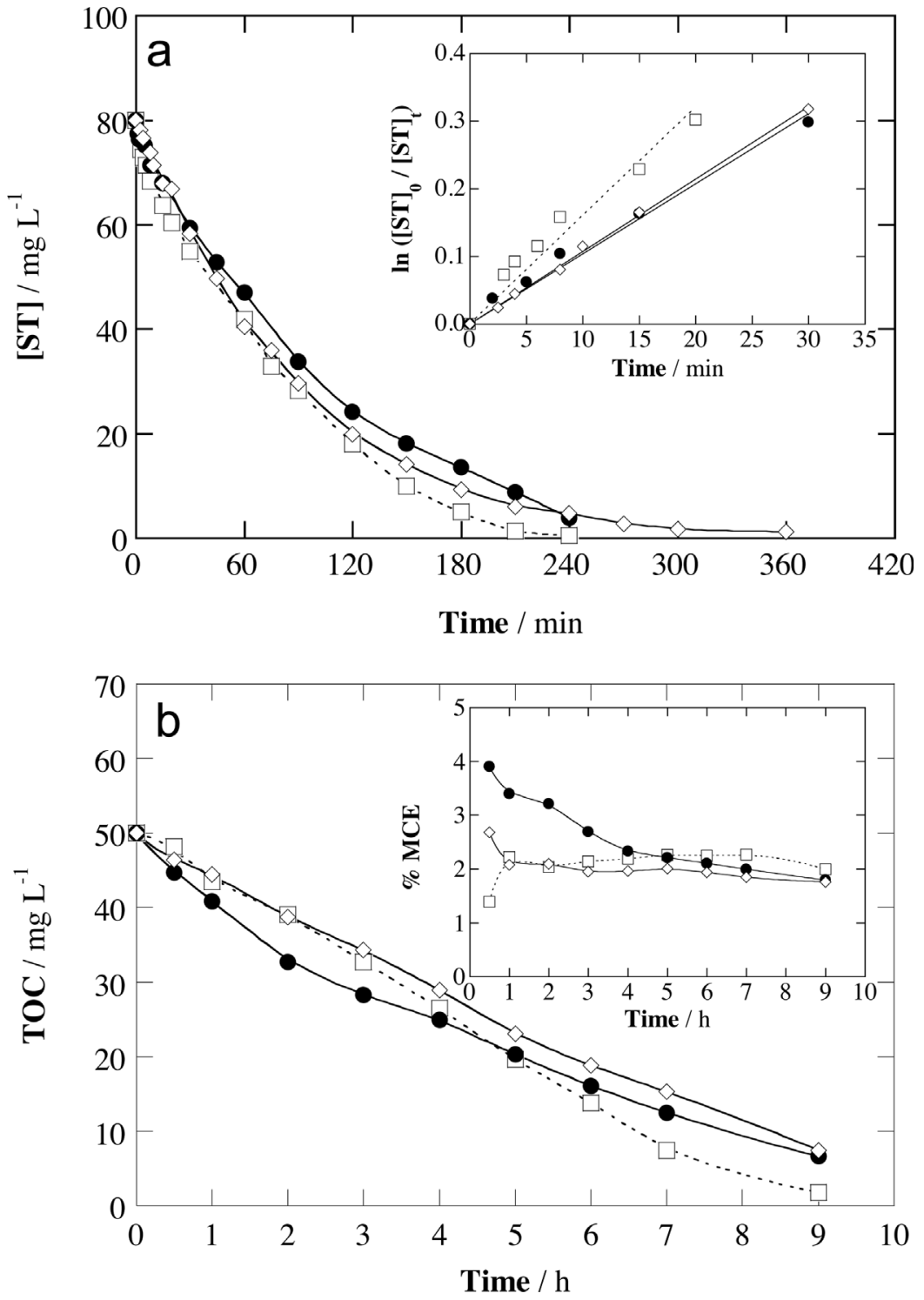

Fig. 1. (a) Concentration decay, (a, inset) kinetic analysis considering a pseudo-first-order reaction, (b) TOC removal and (b, inset) mineralization current efficiency versus time obtained for the electrochemical oxidation with electrogenerated $\mathrm{H}_{2} \mathrm{O}_{2}\left(\mathrm{EO}-\mathrm{H}_{2} \mathrm{O}_{2}\right)$ of $100 \mathrm{~mL}$ of $0.28 \mathrm{mM}$ S-metolachlor (ST) solutions in $0.050 \mathrm{M} \mathrm{Na}_{2} \mathrm{SO}_{4}$ using a stirred $\mathrm{BDD} /$ air-diffusion cell at $300 \mathrm{~mA}$ and $25^{\circ} \mathrm{C}$. Initial pH: $(\square) 3.0,(\bullet) 5.0$ and $(\diamond) 9.0$.
Table 1

Apparent rate constants and $R$-squared for the degradation of herbicide S-metolachlor solutions of $100 \mathrm{~mL}$ with $0.050 \mathrm{M} \mathrm{Na}_{2} \mathrm{SO}_{4}$ by EAOPs using a stirred BDD/air-diffusion cell at $25^{\circ} \mathrm{C}$.

\begin{tabular}{lllllllll}
\hline Method & $\begin{array}{l}{[\mathrm{ST}]} \\
\left.(\mathrm{mg} \mathrm{L})^{-1}\right)\end{array}$ & $\mathrm{pH}$ & $I(\mathrm{~mA})$ & $\begin{array}{l}{\left[\mathrm{Fe}^{2+}\right]} \\
(\mathrm{mM})\end{array}$ & $\begin{array}{l}k_{\mathrm{app}, 1} \\
\left(\mathrm{~min}^{-1}\right)\end{array}$ & $R^{2}$ & $\begin{array}{l}k_{\mathrm{app}, 2} \\
\left(\mathrm{~min}^{-1}\right)\end{array}$ & $R^{2}$ \\
\hline $\mathrm{EO}^{-} \mathrm{H}_{2} \mathrm{O}_{2}$ & 80 & 3.0 & 300 & - & 0.014 & 0.979 & - & - \\
$\mathrm{EO}_{\mathrm{H}} \mathrm{O}_{2}$ & 80 & 5.0 & 300 & - & 0.010 & 0.983 & - & - \\
$\mathrm{EO}-\mathrm{H}_{2} \mathrm{O}_{2}$ & 80 & 9.0 & 300 & - & 0.011 & 0.999 & - & - \\
$\mathrm{EF}$ & 80 & 3.0 & 100 & 0.50 & 0.34 & 0.994 & 0.014 & 0.971 \\
$\mathrm{EF}$ & 80 & 3.0 & 200 & 0.50 & 0.26 & 0.993 & 0.014 & 0.992 \\
$\mathrm{EF}$ & 80 & 3.0 & 300 & 0.50 & 0.16 & 0.992 & 0.030 & 0.987 \\
$\mathrm{EF}$ & 80 & 3.0 & 300 & 0.10 & 0.043 & 0.996 & 0.011 & 0.973 \\
$\mathrm{EF}$ & 80 & 3.0 & 300 & 1.00 & 0.75 & 0.997 & 0.038 & 0.989 \\
$\mathrm{EF}$ & 80 & 3.0 & 300 & 1.50 & 0.45 & 0.981 & 0.063 & 0.979 \\
$\mathrm{EF}$ & 160 & 3.0 & 300 & 0.50 & 0.12 & 0.987 & 0.021 & 0.990 \\
$\mathrm{EF}$ & 40 & 3.0 & 300 & 0.50 & 0.53 & 0.998 & 0.091 & 0.996 \\
$\mathrm{PEF}$ & 80 & 3.0 & 300 & 0.50 & 0.35 & 0.992 & 0.048 & 0.997 \\
\hline
\end{tabular}

being greater than $86 \%$ found at $\mathrm{pH} 5.0$ and 9.0. The inset panel of Fig. 1b depicts the corresponding time course of MCE during the treatments, reaching very low values $(<4 \%)$. This evidences that EO$\mathrm{H}_{2} \mathrm{O}_{2}$ is a rather inefficient process due to the mass transport limitations associated to the fact that the $\operatorname{BDD}(\cdot \mathrm{OH})$ is confined to a small region of the cell and hence, EF was tested as an alternative.

\subsection{Effect of applied current on the EF process}

The applied current has a direct effect on both, the generation rate of $\operatorname{BDD}(\cdot \mathrm{OH})$ at the anode surface from reaction (1) and that of $\mathrm{H}_{2} \mathrm{O}_{2}$ from reaction (2), which in turn affects the formation rate of free $\cdot \mathrm{OH}$ from Fenton's reaction (3). Solutions of $0.28 \mathrm{mM}$ ST with $0.050 \mathrm{M}$ $\mathrm{Na}_{2} \mathrm{SO}_{4}$ and $0.50 \mathrm{mM} \mathrm{Fe}{ }^{2+}$ at $\mathrm{pH} 3.0$ and $25^{\circ} \mathrm{C}$ were treated by EF at current values from 100 to $300 \mathrm{~mA}$.

As can be observed in Fig. 2a, the EF treatment at $300 \mathrm{~mA}$ required only 120 min to completely remove ST, being much quicker than EF at 100 and $200 \mathrm{~mA}(180 \mathrm{~min})$ and $\mathrm{EO}-\mathrm{H}_{2} \mathrm{O}_{2}$ (240 min, Fig. 1a). The faster decay in the presence of $\mathrm{Fe}^{2+}$ catalyst is mainly due to the formation of . $\mathrm{OH}$ in the bulk, overcoming the abovementioned mass transport limitations since the ST molecules can encounter the radicals within the whole cell volume. Moreover, the increase of current from 100 to $300 \mathrm{~mA}$ promoted the gradually larger accumulation of radicals from reaction (1) and (3). The inset panel of Fig. 2a shows a quite different kinetic behavior compared to Fig. 1a. In the presence of $\mathrm{Fe}^{2+}$, two consecutive regions associated to pseudo-first-order kinetics can be observed at all current values. The first region, from 0 to $5 \mathrm{~min}$, presented a very fast ST decay due to the action of $\mathrm{BDD}(\cdot \mathrm{OH})$ and, mainly, 


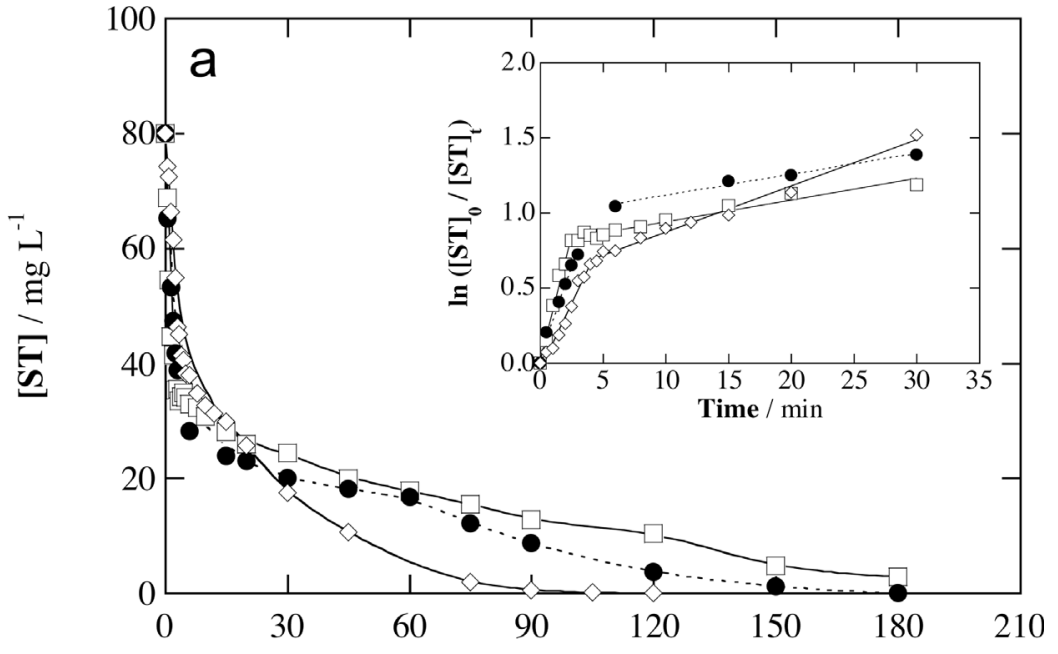

Fig. 2. (a) Concentration abatement, (a, inset) pseudo-first-order kinetics, (b) TOC decay and (b, inset) mineralization current efficiency versus time found for the electro-Fenton (EF) treatment of $100 \mathrm{~mL}$ of $0.28 \mathrm{mM}$ ST solutions with $0.050 \mathrm{M} \mathrm{Na}_{2} \mathrm{SO}_{4}$ and $0.50 \mathrm{mM} \mathrm{Fe}^{2+}$ using a stirred BDD/ air-diffusion cell at $\mathrm{pH} 3.0$ and $25^{\circ} \mathrm{C}$. Applied current: $(\square) 100 \mathrm{~mA}$, $200 \mathrm{~mA}$ and $(\diamond) 300 \mathrm{~mA}$

Time / min

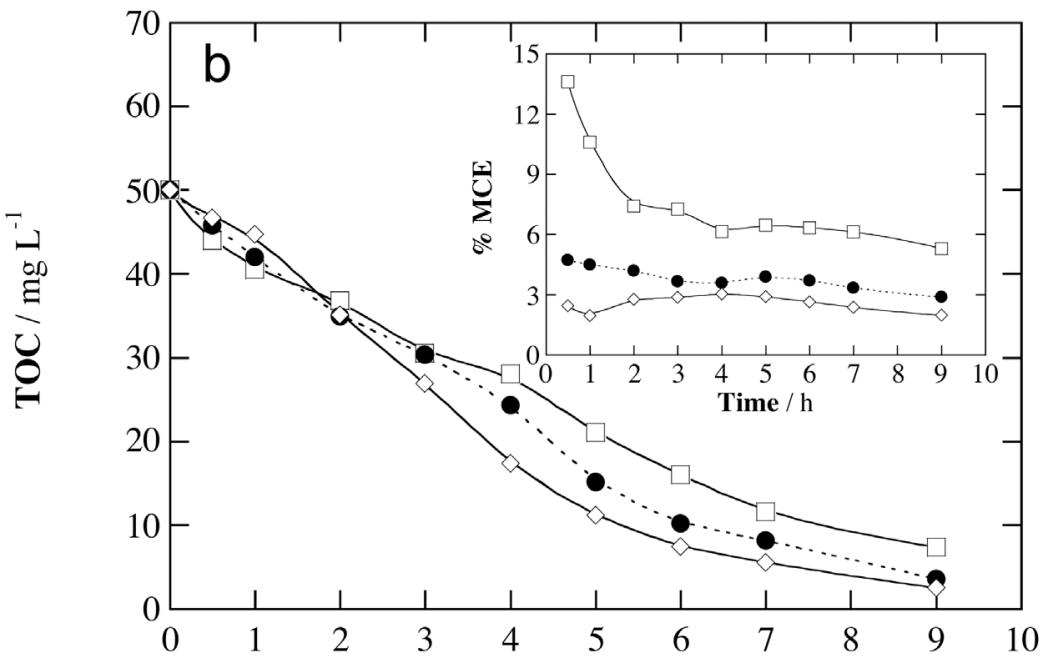

Time / h

the $\cdot \mathrm{OH}$ produced from Fenton's reaction (3). The lower $k_{\text {app }}$ obtained as the applied current was increased (Table 1) can be explained by the faster generation of certain byproducts that compete with ST to react with hydroxyl radicals. The second region, from 5 to $30 \mathrm{~min}$, presented a much slower herbicide concentration decay, with a decrease of about one order of magnitude in the $k_{\text {app }}$ values (Table 1 ). Note that these latter values were close to the $k_{\text {app }}$ found in $\mathrm{EO}-\mathrm{H}_{2} \mathrm{O}_{2}$. This kinetic behavior can be explained as follows: initially, iron ions are in the form of $\mathrm{Fe}^{2+}$, which react with $\mathrm{H}_{2} \mathrm{O}_{2}$ via Fenton's reaction (3) and produce large amounts of $\cdot \mathrm{OH}$; however, the regeneration of $\mathrm{Fe}^{2+}$ from reaction (4) is difficult [29], favoring the formation of complexes between $\mathrm{Fe}$ (III) and ST and hence, after 5 min of electrolysis these remaining complexes are mainly degraded only by $\operatorname{BDD}(\cdot \mathrm{OH})$, as occurs in EO$\mathrm{H}_{2} \mathrm{O}_{2}$. Therefore, the inflection point appears once the ST concentration is low enough so as to form Fe(III)-ST complexes to a large extent. The existence of two consecutive degradation regions related to the formation of Fe(III) complexes has also been reported for the EF treatment of another $N$-compound, i.e., the insecticide propoxur [20].

The TOC removals corresponding to the same trials are shown in Fig. 2b. As in the case of Fig. 1a, there was no remarkable difference within the first minutes of EF treatment. Conversely, the mineralization was much quicker from 2 to $3 \mathrm{~h}$ of treatment, attaining $85 \%, 93 \%$ and $95 \%$ after $9 \mathrm{~h}$ at 100, 200 and $300 \mathrm{~mA}$, respectively. The superiority of the higher current values can be due to the favored $\mathrm{Fe}^{2+}$ regeneration with higher $\cdot \mathrm{OH}$ production in the bulk once ST has been totally removed. The inset depicts the MCE values, which attained $13 \%$ as maximal during the first minutes at $100 \mathrm{~mA}$, and always became progressively lower as the current was raised. This can be accounted for by the greater extent of parasitic reactions (8)-(11) as current increases [29-32]. Reaction (8) is the most important side reaction since $\mathrm{O}_{2}$ evolution is largely enhanced removing a larger proportion of $\mathrm{BDD}(\cdot$ $\mathrm{OH})$. The greater $\mathrm{H}_{2} \mathrm{O}_{2}$ production also reduces the $\cdot \mathrm{OH}$ concentration in the bulk via reaction (9) with generation of the weak hydroperoxyl radical $\left(\mathrm{HO}_{2} \cdot\right)$. The quicker rise in $\mathrm{O}_{3}$ and $\mathrm{S}_{2} \mathrm{O}_{8}{ }^{2-}$ generation from electrode reactions (10) and (11) also inhibits the anodic production of $\mathrm{BDD}\left({ }^{\circ} \mathrm{OH}\right)$ from reaction $(1)$.

$2 \mathrm{BDD}\left({ }^{\circ} \mathrm{OH}\right) \rightarrow 2 \mathrm{BDD}+\mathrm{O}_{2}+2 \mathrm{H}^{+}+2 \mathrm{e}^{-}$

$\mathrm{H}_{2} \mathrm{O}_{2}+{ }^{\cdot} \mathrm{OH} \rightarrow \mathrm{HO}_{2}^{*}+\mathrm{H}_{2} \mathrm{O}$

$3 \mathrm{H}_{2} \mathrm{O} \rightarrow \mathrm{O}_{3}+6 \mathrm{H}^{+}+6 \mathrm{e}^{-}$

$2 \mathrm{SO}_{4}^{2-} \rightarrow \mathrm{S}_{2} \mathrm{O}_{8}^{2-}+2 \mathrm{e}^{-}$

\subsection{Effect of initial $\mathrm{Fe}^{2+}$ concentration on the EF process}

To assess the influence of the content of $\mathrm{Fe}^{2+}$ catalyst on the $\mathrm{EF}$ process, $0.28 \mathrm{mM}$ ST solutions with $0.050 \mathrm{M} \mathrm{Na}_{2} \mathrm{SO}_{4}$ were treated at $\mathrm{pH}$ 


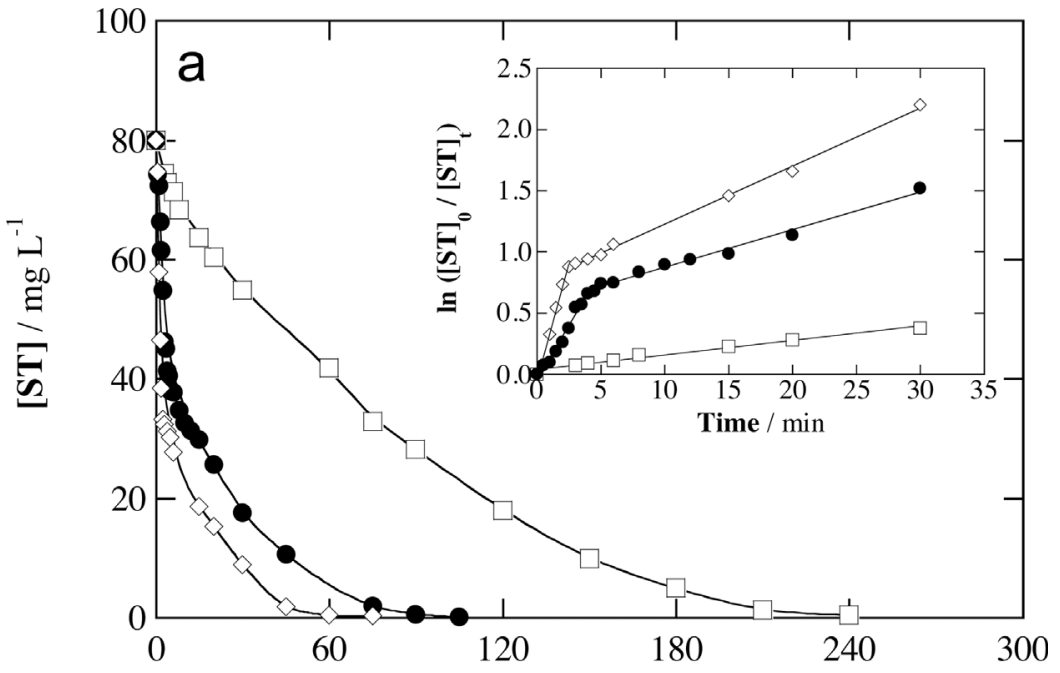

Time / $\min$

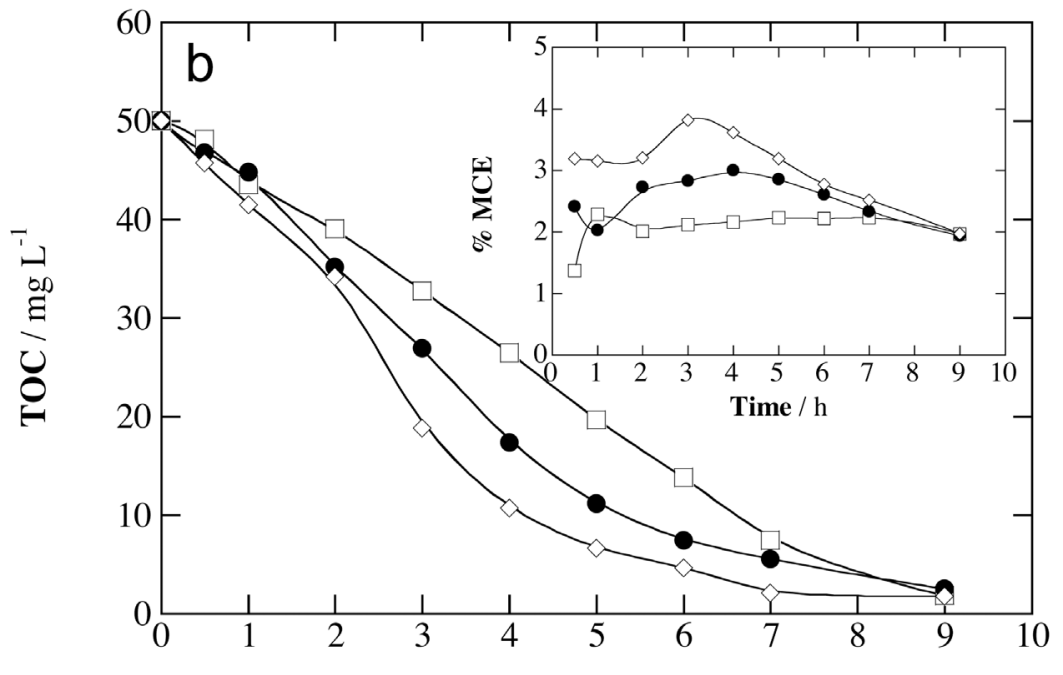

Time / h
Fig. 3. (a) Concentration abatement, (a, inset) pseudo-first-order kinetics, (b) TOC reduction and (b, inset) mineralization current efficiency versus time determined for the treatment of $100 \mathrm{~mL}$ of $0.28 \mathrm{mM}$ ST solutions with $0.050 \mathrm{M} \mathrm{Na}_{2} \mathrm{SO}_{4}$ at $\mathrm{pH} 3.0$ using a stirred $\mathrm{BDD} /$ air-diffusion cell at $300 \mathrm{~mA}$ and $25{ }^{\circ} \mathrm{C}$. Method: $(\square) \mathrm{EO}-\mathrm{H}_{2} \mathrm{O}_{2},(\bullet) \mathrm{EF}$ with $0.50 \mathrm{mM} \mathrm{Fe}^{2+}$ and $(\diamond)$ photoelectro-Fenton (PEF) with $0.50 \mathrm{mM} \mathrm{Fe}{ }^{2+}$ under irradiation with a 4 W UVA lamp.
3.0 and $300 \mathrm{~mA}$ upon addition of $0.10-1.50 \mathrm{mM} \mathrm{Fe}^{2+}$. As can be seen in Fig. S1a, a quicker ST decay resulted from increasing the initial $\mathrm{Fe}^{2+}$ concentration, needing 270, 120, 75 and $60 \mathrm{~min}$ for total ST removal at $0.10,0.50,1.00$ and $1.50 \mathrm{mM} \mathrm{Fe}^{2+}$, respectively. Again, two consecutive regions agreeing with a pseudo-first-order kinetics, were found (see the inset of Fig. S1a). The decay in the first region was much more rapid than in the second one, as confirmed from $k_{\text {app }}$ values in Table 1. Note that, in the first region, the abatement of the herbicide at $1.50 \mathrm{mM}$ $\mathrm{Fe}^{2+}$ was slower than that at $1.00 \mathrm{mM}$, which can be related to the decay of available $\cdot \mathrm{OH}$ in the bulk by its consumption in the parasitic reaction between hydroxyl radicals and $\mathrm{Fe}^{2+}$ species $[29,30]$. The kinetics at the lowest $\mathrm{Fe}^{2+}$ concentration was quite similar to that of EO$\mathrm{H}_{2} \mathrm{O}_{2}$, as confirmed from the analogous $k_{\text {app }}$ values obtained (Table 1).

Fig. S1b shows that the mineralization attained at $9 \mathrm{~h}$ was $83 \%$ at $0.10 \mathrm{mM} \mathrm{Fe}{ }^{2+}$, and up to $95 \%$ at $0.50-1.50 \mathrm{mM}$. Although slightly quicker TOC abatements can be seen as the $\mathrm{Fe}^{2+}$ content was increased from $0.50 \mathrm{mM}$, the accumulation of refractory complexes formed between $\mathrm{Fe}(\mathrm{III})$ and some byproducts like short-chain carboxylic acids caused the deceleration of the degradation at long treatment time, eventually ending in similar abatements. The inset shows the MCE values along the electrolyses, which were somewhat greater at high $\mathrm{Fe}^{2+}$ concentration during the first hours, but tended to become equal at the end of the treatments.

\subsection{Effect of initial ST concentration on the EF process}

The influence of the initial ST content on the EF performance was studied by treating solutions with concentrations between 0.14 and $0.56 \mathrm{mM}$ in $0.050 \mathrm{M} \mathrm{Na}_{2} \mathrm{SO}_{4}$ with $0.50 \mathrm{mM} \mathrm{Fe}^{2+}$ at $\mathrm{pH} 3.0$ and $300 \mathrm{~mA}$. Fig. S2a highlights a total ST removal in all cases, requiring 60, 105 and $360 \mathrm{~min}$ upon gradual ST increase. This agrees with the expected analogous concentration of hydroxyl radicals available in the three cases, which is then used for reacting with a gradually larger number of ST molecules. Two different slopes appeared upon kinetic analysis of consecutive regions (see inset panel of Fig. S2a and $k_{\text {app }}$ values in Table 1), as explained above. Quite similar normalized TOC removals were obtained regardless of the initial ST concentration, as shown in Fig. S2b, achieving $92 \%, 96 \%$ and $88 \%$ for $0.14,0.28$ and $0.56 \mathrm{mM}$, respectively. The MCE of the EF treatment was then enhanced as the ST content was raised (see the inset panel of Fig. S2b), reaching $4.8 \%$ for $0.56 \mathrm{mM}$ ST and $1.3 \%$ for $0.14 \mathrm{mM} \mathrm{ST}$ after $9 \mathrm{~h}$. This behavior suggests that parasitic reactions (8)-(11) were given to a lower extent since hydroxyl radicals and $\mathrm{H}_{2} \mathrm{O}_{2}$ were able to encounter organic molecules more easily, which is very positive whenever concentrated effluents containing this herbicide have to be treated by EF process. 


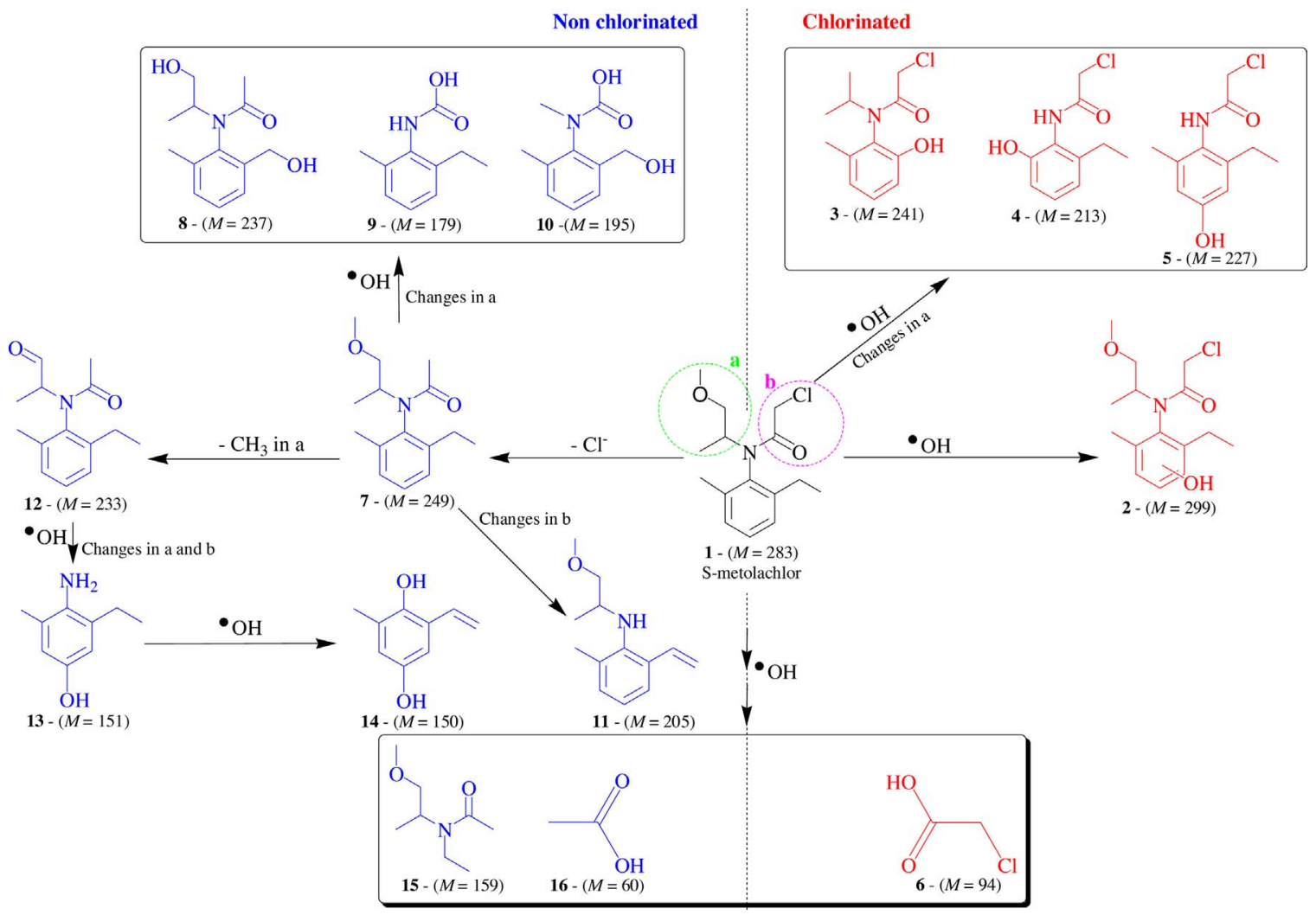

Fig. 4. Scheme of the possible routes for S-metolachlor degradation proposed from all the by-products identified by GC-MS.

\subsection{Degradation of S-metolachlor by PEF}

Aiming to promote a faster degradation of ST, the performance of EO- $\mathrm{H}_{2} \mathrm{O}_{2}$ and EF treatments of $0.28 \mathrm{mM}$ ST solutions with $0.050 \mathrm{M}$ $\mathrm{Na}_{2} \mathrm{SO}_{4}$ at $\mathrm{pH} 3.0$ and $300 \mathrm{~mA}$ was compared with that of PEF using $0.50 \mathrm{mM} \mathrm{Fe}^{2+}$ and a $4 \mathrm{~W}$ UVA lamp. Fig. 3 informs about the remarkable superiority of PEF under those comparable conditions, being especially substantial for the herbicide concentration decay. ST was totally abated after 240,75 and $45 \mathrm{~min}$ by $\mathrm{EO}-\mathrm{H}_{2} \mathrm{O}_{2}$, EF and PEF, respectively, as shown in Fig. 3a. This means that the UVA radiation was quite effective for ensuring the regeneration of $\mathrm{Fe}^{2+}$ from photo-Fenton reaction (5), as confirmed in the inset. Two consecutive pseudo-firstorder kinetics were also obtained in PEF, as in EF, although with a more pronounced slope of the straight lines in the two regions (see $k_{\text {app }}$ values in Table 1). This can be related to the quicker ST destruction in PEF by the action of additional $\cdot \mathrm{OH}$ induced by reaction (5), which causes the faster formation of Fe(III)-ST complexes with the consequent appearance of the inflection point at shorter time compared to EF. These results agree with those reported recently for the inseticide propoxur, which conforms the formation of Fe(III) complexes [20]. The oxidation ability of the EAOPs then increased in the order EO$\mathrm{H}_{2} \mathrm{O}_{2}<\mathrm{EF}<\mathrm{PEF}$. In contrast, the TOC decay attained at $9 \mathrm{~h}$ was similar in the three processes, with around $95 \%$ of mineralization (see Fig. 3b), which can be explained by the great persistence of final byproducts, either free or complexed with $\mathrm{Fe}(\mathrm{III})$. These species are preeminently destroyed by $\operatorname{BDD}(\cdot \mathrm{OH})$, presenting a much slower kinetic constant with $\cdot \mathrm{OH}$ in the bulk. The similar MCE values achieved during the three treatments after some initial minutes (inset of Fig. 3b) confirm the formation of refractory compounds and/or complexes.

\subsection{Main degradation routes}

Based on the byproducts identified by GC-MS during the treatment of ST solutions by the three EAOPs, the possible degradation pathways are proposed in Fig. 4. Two sets of compounds were found, including chlorinated and non-chlorinated compounds. The first set appeared upon hydroxylation of ST (1), which yielded $\mathbf{2}$ from the single attack of $\cdot \mathrm{OH} / \mathrm{BDD}(\cdot \mathrm{OH})$ onto the benzene ring or 3, 4 and 5 if concomitant changes in the $-\mathrm{NCH}\left(\mathrm{CH}_{3}\right) \mathrm{CH}_{2} \mathrm{OCH}_{3}$ group occurred. All these byproducts maintained the initial $-\mathrm{COCH}_{2} \mathrm{Cl}$ group, but the attack of hydroxyl radicals onto the carbonyl group of these compounds favored the formation of chloracetic acid (6), which is known to be a very refractory molecule to $\cdot \mathrm{OH}$ formed from Fenton's reaction (3) [39]. The second set of compounds was formed upon $\mathrm{Cl}^{-}$release to form dechlorinated ST (7). Hydroxylation of the ethyl group bonded to the aromatic ring or the side group $a$, with or without changes in $b$, yielded 8, 9 and 10. Alternatively, changes in the side group $b$ yielded compound 11, whose ethyl group is also modified. Demethylation of 7 explains the formation of 12, whereas subsequent hydroxylation in para position yielded the aminophenol 13. Hydroquinone 14 appeared upon attack of hydroxyl radicals on the amino position of the aromatic ring. Finally, the cleavage of the previous aromatic byproducts ended in aliphatic compound 15 along with acetic acid (16). Nitrogen atom contained in ST or any of its byproducts was mainly accumulated as ammonium ion, as described in reaction (8).

\section{Conclusions}

The application of EAOPs to treat aqueous solutions contaminated with ST was thoroughly evaluated. It has been shown that the rate of degradation and mineralization for solutions with $0.28 \mathrm{mM}$ ST treated by $\mathrm{EO}-\mathrm{H}_{2} \mathrm{O}_{2}$ is slightly higher at $\mathrm{pH}$ 3.0. However, at that $\mathrm{pH}$, the performance of $\mathrm{EF}$ was much better thanks to the formation of hydroxyl radicals in the bulk, which overcome the mass transport limitations that are typical in EO. The decay kinetics in all the EF trials presented two well-defined regions, being the second one much slower than the first, which is associated to the formation of Fe(III)-ST complexes that hamper the $\mathrm{Fe}^{2+}$ regeneration. The increase in current and $\mathrm{Fe}^{2+}$ 
concentration was beneficial since the treatments were accelerated, but lower MCE values were obtained. EF was more efficient at higher initial ST concentrations due to the minimization of parasitic reactions. In PEF treatment, which also presented two regions related to pseudo-firstorder kinetics, the abatement of ST was clearly upgraded, although the degree of mineralization by $\mathrm{EO}-\mathrm{H}_{2} \mathrm{O}_{2}$, EF and PEF was quite similar because complexed and uncomplexed byproducts turned out to be refractory. Up to 15 byproducts, including chlorinated and non-chlorinated ones, have been identified by GC-MS.

\section{Acknowledgments}

The authors thank financial support from Brazilian funding agencies: Fundação de Apoio ao Desenvolvimento do Ensino, Ciência e Tecnologia do Estado de Mato Grosso do Sul (FUNDECT-MS), PróReitoria de Pesquisa e Pós-Graduação da Universidade Federal de Mato Grosso do Sul (PROPP-UFMS), Coordenação de Aperfeiçoamento de Pessoal de Nível Superior (CAPES), and Conselho Nacional de Desenvolvimento Científico e Tecnológico (CNPQ). Financial support from project CTQ2016-78616-R (AEI/FEDER, EU) is also acknowledged.

\section{Appendix A. Supplementary data}

Supplementary data associated with this article can be found, in the online version, at http://dx.doi.org/10.1016/j.cattod.2017.10.026.

\section{References}

[1] A. De, R. Bose, A. Kumar, S. Mozumdar, Targeted Delivery of Pesticides Using Biodegradable Polymeric Nanoparticles, Springer, New Delhi, 2014.

[2] P.J. O'Connell, C.T. Harms, J.R.F. Allen, Metolachlor, S-metolachlor and their role within sustainable weed-management, Crop Prot. 17 (1998) 207-212.

[3] United States Environmental Protection Agency, Re-registration Eligibility Decision (RED): Metolachlor, 1995. Available at: https://archive.epa.gov/pesticides/ reregistration/web/pdf/0001.pdf Accessed in 01 May 2017.

[4] World Health Organization, Guidelines for Drinking-Water Quality, 4th ed., (2011) (Geneva) Available at: http://apps.who.int/iris/bitstream/10665/44584/1/ 9789241548151 eng.pdf Accessed in 01 May, 2017.

[5] L. Rivard, Environmental Fate of Metolachlor, (2003) (Available at: http://cdpr.ca. gov/docs/emon/pubs/fatememo/metolachlor.pdf Accessed in 01 May 2017).

[6] Agência Nacional de Vigilância Sanitária. Monografias Autorizadas: S13-S-metolacloro, 2014. Available at: http://portal.anvisa.gov.br/documents/111215/117782/ S13\%2BS\%2BMetolacloro\%2Batual.pdf/964f38ac-f7c9-4a57-b1e0-1c99ee5f939b Accessed in 01 May 2017.

[7] M. Thakkar, V. Randhawa, L. Wei, Comparative responses of two species of marine phytoplankton to metolachlor exposure, Aquat. Toxicol. 126 (2013) 198-206.

[8] C. Quintaneiro, D. Patrício, S.C. Novais, A.M.V.M. Soares, M.S. Monteiro, Endocrine and physiological effects of linuron and S-metolachlor in zebrafish developing embryos, Sci. Total Environ. 586 (2017) 390-400.

[9] H. Mai, B. Morin, P. Pardon, P. Gonzalez, H. Budzinski, J. Cachot, Environmenta concentrations of irgarol diuron and S-metolachlor induce deleterious effects on gametes and embryos of the Pacific oyster, Crassostrea gigas, Mar. Environ. Res. 89 (2013) 1-8.

[10] S. Hartnett, S. Musah, K.R. Dhanwada, Cellular effects of metolachlor exposure on human liver (HepG2) cells, Chemosphere 90 (2013) 1258-1266.

[11] V.A. Sakkas, I.M. Arabatzis, I.K. Konstantinou, A.D. Dimou, T.A. Albanis, P. Falaras, Metolachlor photocatalytic degradation using $\mathrm{TiO}_{2}$ photocatalysts, Appl. Catal. B: Environ. 49 (2004) 195-205.

[12] P.L. Huston, J.J. Pignatello, Degradation of selected pesticide active ingredients and commercial formulations in water by the photo-assisted Fenton reaction, Water Res. 33 (1999) 1238-1246.

[13] J.J. Pignatello, Y. Sun, Complete oxidation of metolachlor and methyl parathion in water by the photoassisted Fenton reaction, Water Res. 29 (1995) 1837-1844.

[14] K. Pratap, A.T. Lemley, Fenton electrochemical treatment of aqueous atrazine and metolachlor, J. Agric. Food Chem. 46 (1998) 3285-3291.

[15] A. Da Pozzo, C. Merli, I. Sirés, J.A. Garrido, R.M. Rodríguez, E. Brillas, Removal of the herbicide amitrole from water by anodic oxidation and electro-Fenton, Environ. Chem. Lett. 3 (2005) 7-11.
[16] E. Brillas, M.A. Baños, M. Skoumal, P.L. Cabot, J.A. Garrido, R.M. Rodríguez, Degradation of the herbicide 2,4-DP by anodic oxidation, electro-Fenton and photoelectro-Fenton using platinum and boron-doped diamond anodes, Chemosphere 68 (2007) 199-209.

[17] A. Kesraoui-Abdesalem, N. Oturan, N. Bellakhal, M. Dachraoui, M.A. Oturan, Experimental design methodology applied to electro-Fenton treatment for degradation of herbicide chlortoluron, Appl. Catal. B: Environ. 78 (2008) 334-341.

[18] M.A. Rodrigo, N. Oturan, M.A. Oturan, Electrochemically assisted remediation of pesticides in soils and water: a review, Chem. Rev. 114 (2014) 8720-8745.

[19] P.A. Diaw, N. Oturan, M.D. Gaye-Seye, A. Coly, A. Tine, J.-J. Aaron, M.A. Oturan, Oxidative degradation and mineralization of the phenylurea herbicide fluometuron in aqueous media by the electro-Fenton process, Sep. Purif. Technol. 186 (2017) 197-206.

[20] D.R.V. Guelfi, F. Gozzi, I. Sirés, E. Brillas, A. Machulek Jr., S.C. de Oliveira, Degradation of the insecticide propoxur by electrochemical advanced oxidation processes using a boron-doped diamond/air-diffusion cell, Environ. Sci. Pollut. Res. 24 (2017) 6083-6095.

[21] C. Flox, J.A. Garrido, R.M. Rodríguez, P.L. Cabot, F. Centellas, C. Arias, E. Brillas, Mineralization of herbicide mecoprop by photoelectro-Fenton with UVA and solar light, Catal. Today 129 (2007) 29-36.

[22] F. Gozzi, I. Sirés, A. Thiam, S.C. de Oliveira, A. Machulek Jr., E. Brillas, Treatment of single and mixed pesticide formulations by solar photoelectro-Fenton using a flow plant, Chem. Eng. J. 310 (2017) 503-513.

[23] A. El-Ghenymy, F. Centellas, R.M. Rodríguez, P.L. Cabot, J.A. Garrido, I. Sirés, E. Brillas, Comparative use of anodic oxidation, electro-Fenton and photoelectroFenton with Pt or boron-doped diamond anode to decolorize and mineralize Malachite Green oxalate dye, Electrochim. Acta 182 (2015) 247-256.

[24] A. Thiam, I. Sirés, J.A. Garrido, R.M. Rodríguez, E. Brillas, Decolorization and mineralization of Allura Red AC aqueous solutions by electrochemical advanced oxidation processes, J. Hazard. Mater. 290 (2015) 34-42.

[25] A.J. Bañuelos, O. García-Rodríguez, A. El-Ghenymy, F.J. Rodríguez-Valadez, L.A. Godínez, E. Brillas, Advanced oxidation treatment of malachite green dye using a low cost carbon-felt air-diffusion cathode, J. Environ. Chem. Eng. 4 (2016) 2066-2075.

[26] A. Bedolla-Guzman, I. Sirés, A. Thiam, J.M. Peralta-Hernández, S. GutiérrezGranados, E. Brillas, Application of anodic oxidation, electro-Fenton and UVA photoelectro-Fenton to decolorize and mineralize acidic solutions of Reactive Yellow 160 azo dye, Electrochim. Acta 206 (2016) 307-316.

[27] G. Coria, I. Sirés, E. Brillas, J.L. Nava, Influence of the anode material on the degradation of naproxen by Fenton-based electrochemical processes, Chem. Eng. J. 304 (2016) 817-825.

[28] J.R. Steter, E. Brillas, I. Sirés, On the selection of the anode material for the electrochemical removal of methylparaben from different aqueous media, Electrochim. Acta 222 (2016) 1464-1474.

[29] E. Brillas, I. Sirés, M.A. Oturan, Electro-Fenton process and related electrochemical technologies based on Fenton's reaction chemistry, Chem. Rev. 109 (2009) 6570-6631.

[30] I. Sirés, E. Brillas, M.A. Oturan, M.A. Rodrigo, M. Panizza, Electrochemical advanced oxidation processes: today and tomorrow. A review, Environ. Sci. Pollut. Res. 21 (2014) 8336-8367.

[31] I. Sirés, E. Brillas, Remediation of water pollution caused by pharmaceutical residues based on electrochemical separation and degradation technologies: a review, Environ. Int. 40 (2012) 212-229.

[32] C.A. Martínez-Huitle, M.A. Rodrigo, I. Sirés, O. Scialdone, Single and coupled electrochemical processes and reactors for the abatement of organic water pollutants: a critical review, Chem. Rev. 115 (2015) 13362-13407.

[33] C.G. Hatchard, C.A. Parker, A new sensitive chemical actinometer - II. Potassium ferrioxalate as a standard chemical actinometer, Proc. R. Soc. A 235 (1956) 518-536.

[34] Environmental Protection Agency - SW 846, Testing Methods for Evaluating Solid Wastes: Physical/Chemical Methods, 3rd, (2015) (final update V).

[35] American Public Health Association, American Works Association, Water Environment Federation, Standard Methods for the Examination of Water and Wastewater, 22nd, (2012) (Washington, DC).

[36] E. Guinea, C. Arias, P.L. Cabot, J.A. Garrido, R.M. Rodríguez, F. Centellas, E. Brillas, Mineralization of salicylic acid in acidic aqueous medium by electrochemical advanced oxidation processes using platinum and boron-doped diamond as anode and cathodically generated hydrogen peroxide, Water Res. 42 (2008) 499-511.

[37] E. Brillas, M.A. Baños, J.A. Garrido, Mineralization of herbicide 3,6-dichloro-2methoxybenzoic acid in aqueous medium by anodic oxidation, electro-Fenton and photoelectro-Fenton, Electrochim. Acta 48 (2003) 1697-1705.

[38] T.A. Enache, A.M. Chiorcea-Paquim, O. Fatibello-Filho, A.M. Oliveira-Brett, Hydroxyl radicals electrochemically generated in situ on a boron-doped diamond electrode, Electrochem. Commun. 11 (2009) 1342-1345.

[39] S. Randazzo, O. Scialdone, E. Brillas, I. Sirés, Comparative electrochemical treatments of two chlorinated aliphatic hydrocarbons. Time course of the main reaction by-products, J. Hazard. Mater. 192 (2011) 1555-1564. 